\begin{tabular}{|c|c|}
\hline & $\begin{array}{l}\text { International Journal of Trend in Scientific } \\
\text { Research and Development (IJTSRD) }\end{array}$ \\
\hline 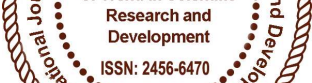 & International Open Access Journal \\
\hline 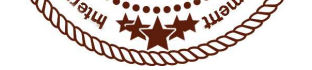 & ISSN No: 2456 - 6470 | www.ijtsrd.com | Volume - 2 | Issue - 2 \\
\hline
\end{tabular}

\title{
Intergrated Training Model of Business Skills for Kawedegan Farmers, Nganjuk-East Java Indonesia
}

\author{
Lena Ellitan, Teodora Winda Mulia, Lodovicus Lasdi \\ Faculty of Business, Widya Mandala Catholic University, Surabaya, Indonesia
}

\begin{abstract}
This research is motivated by the living conditions of smallholder forestry land in Kawedegan, Balonggebang, Gondang District, Nganjuk-East Java that besides the level of education is low, and also they do not have a fixed income. Perhutani land peasant farming sweet potatoes and crops. The objective of this study is to find out a model of skills training in an integrated effort as empowering farming communities in developing entrepreneurship skills. The approach used in the study is an action research. Research model of integrated business skills training for farmers as community empowerment $S$ are implemented through two forms of activity in two years. In the first year, the researchers conducted a qualitative exploration, and in the second year it will be proceed by doing experimental design. This paper focuses on the discussion of exploratory study with

establish trust and mobilize the grassroots base to support rural development programme.

\section{INTRODUCTION}

\subsection{Background of the Study}

The agricultural sector is a sector that has a strategic role $J$ in the structure of national economic development. This sector is a sector that does not get serious attention from the government in nation building. Starting from protection, credit to other policies is not one that is beneficial to the sector. Agricultural development programs that are not directed to the goal even further plunge the sector to destruction. Yet this sector is a very large sector of labor and most of our people depend on it.
\end{abstract} exploring and collecting information about the needs of development, specifically in the context of economic development in dusun kawedegan which are still dominated by the agricultural sector. Villagers in Kawedegan hope that the function and role of microfinance institutions is a venture capital provider. One of the outputs of this activity is the formation of Microfinance Institutions (MFIs) to enhance access to finance for smallholder land PERHUTANI. Smallholder land PERHUTANI seeks funding support to start developing a business independently. On 1 September 2013, MFIs in the form of a credit union (CU) was established in Kawedegan, Balonggebang Village, Gondang District, Nganjuk East Java. Credit union is one of the methodologies to create effective economic empowerment of the people as well as to
BPS (2013) divides districts in Indonesia based on pockets of poverty into three categories, one group means districts with very poor families, group two means districts with poor families, and group of three means districts with poor families. Nganjuk District which is part of East Java Province, including group two. Kawedegan, Balonggebang Village, Gondang District, is one of the pockets of poverty in Nganjuk. The village is a small hamlet on the edge of the teak forest. The soil conditions are less fertile and contain lots of lime. Farms rely heavily on rain. If not, then irrigation for agriculture is done by buying water to the owners of drilled wells, it means that this can only be done by farmers who have enough capital. Agricultural crops developed here include rice, sweet potato, corn, lombok, onion, melon and palawija. 
The villagers have a low level of education. In addition to cost, awareness of the importance of education is also still very less. Most of the people are illiterate, not just the parents, the younger generation are still illiterate. Even if there is a school, the highest only graduate Elementary School. People's economic lives are below the poverty line and generally work as farm laborers, firewood searchers and teak leaves in the forest. Only a small portion owns its own farmland, and that is only a small patch. While people who migrate to the city, working as factory workers and domestic workers. This condition is caused by poverty, low level of education, and the absence of special skills they have.

From the various limitations of surrounding forest resources, as mentioned above, globalization in various aspects of social economy has in fact become a serious threat to the development effort and the improvement of the welfare of farmers community. Although also realized an opportunity if it can be realized a guidance to the community as through skills training in an integrated from various elements. Integrated skills training activities will be able to assist communities in finding livelihoods and entrepreneurship capabilities in accordance with the potential of the environment to increase the income or welfare of farmers.

Previous studies that have investigated farmer-related training in community empowerment demonstrate the need for an integrated entrepreneurship-based entrepreneurship training model. Sukarta (2010) research on the influence of environment, entrepreneurship, and entrepreneurial motivation on entrepreneurial learning and business performance. This research was conducted on the business of broiler breeder in Tabanan regency. The results showed that entrepreneurial learning and business growth are influenced directly and significantly by business motivation, entrepreneurial learning gives direct influence to business performance.

Research model of integrated business skill training for farmers as community empowerment effort implemented through two forms of activity in two years. The first year the researcher conducted a qualitative exploration, and the second year experimental design. Exploration study activities include 1) researching and gathering information about development needs, 2) planning prototype components to be developed including defining the type of business skills to be developed, formulating objectives, determining the sequence of activities and making measurement scale (research instrument); 3 ) developing prototype beginning to model, 4) validating conceptual models to experts or practitioners. The second year activities include 1) conducting limited trials of the initial model, 2) revising the initial model, based on test results and data analysis, 3) conducting extensive trials, 4) final revision or model refinement, if researchers and stakeholders assess the process and the resulting product model has not been satisfactory. This paper focuses on the results of the one-phase study that has been done.

\subsection{Problem Formulation}

The limited ability experienced by the community around the forest is the result of previously less empowered in community forest management (PHBM), thus causing poverty for farmers in forest villages. The inability of rural communities to be identical with poverty is always relevant to the level of education, health, and nutrition resulting in low productivity.

Family farmers in Kawedegan, Balonggebang Village, Gondang District, Nganjuk included in the category of pre prosperous family. This situation makes them have no capital to open a business or to develop other agricultural businesses. Own land itself was forced to be done in a way as simple as possible. For example because of water limitations, plants that should be watered 2 times a day, only able to watered 2 days or just by relying on rain water only. Fertilizers purchased for plants are also the least expensive or low quality, often not even nurtured at all. Landless families, working as farm laborers, are only calling landowners and usually seek additional income by searching for firewood, teak leaves, caterpillar cocoons, grasshoppers, snails in the forest. Everything is only seasonal. Not infrequently the farm workers must be unemployed.

In general, the problem to be studied in this research is "How is the model of integrated business skill training for the farmers of Perhutani land as an effort to transfer the commodity in Kawedegan, Balonggebang Village, Gondang district, NganjukEast Java. Start from the problem, then detailed in some questions research as follows: What is the condition of farmer community and agricultural environment of Kawedegan, Balonggebang Village, 
Gondang district, Nganjuk Regency which serve as the target of integrated business skill training with yam, cultivate and entrepreneur?

\subsection{Research Objectives}

This research is generally aimed to find an integrated business skill training model that is effective in solving the problems faced by agrarian society after the enactment of the ban on working on the land of Perhutani with certain commodities. The objectives of the research can be elaborated on: To obtain data on the condition of the farming community and the agricultural environment of Kawedegan, Balonggebang Village, Gondang Subdistrict, Nganjuk Regency which will serve as the target of integrated business skills training with cassava, beans farmers, cultivating and entrepreneurial species.

\section{LITERATURE REVIEW}

\subsection{State of the Art of the Research}

The researches that have been conducted on business training and entrepreneurship have strengthened the evidence that the role of business skills and entrepreneurship can empower villagers, especially farmers. Research Sukatra (2010) about the influence of environment, entrepreneurship, and entrepreneurial motivation of entrepreneurial learning and business performance. This research was conducted on the business of broiler breeder in Tabanan regency. The purpose of this study is to see the significance of the direct or indirect effects of each exogenous variable on endogenous variables, in this case the variables of entrepreneurial learning and business growth. Respondents from this research are direct owners or managers of the business with a total sample of 130 business units taken using Stratified Random Sampling method. Data were analyzed by using Path analysis.

Sukatra (2010) argues that the remote environment does not provide positive support for business growth, while the industrial and internal environment is quite good. The business environment has no direct effect on entrepreneurial learning. The business environment has a significant direct effect on business motivation. The business environment has no effect on the formation of entrepreneurial traits, the nature of entrepreneurship influences entrepreneurial learning and direct business motivation, but on the growth of its business influence is not directly. Entrepreneurship learning and business growth are influenced directly and significantly by business motivation, entrepreneurial learning gives direct influence to business performance.

Research Udayani (2010) about the relationship between the entrepreneurial spirit with the success of agribusiness (case on the broiler farms in Bali). This study discusses how the level of life of broiler breeders in Bali, how the relationship between entrepreneurship spirit, the ability of agribusiness application, and the characteristics of breeders, with the success of agribusiness broiler, and how the influence of entrepreneurial spirit, the ability of the application of agribusiness, breeders, with the success of broiler agribusiness, and analyzing the pangaruh entrepreneurial spirit, the ability of the application of agribusiness, and the characteristics of breeders, to the success of agribusiness broiler.

The results of this study indicate that there is a strong relationship between the entrepreneurial spirit with the ability of the application of agribusiness. There is a strong relationship between the entrepreneurial spirit with the characteristics of breeders and the relationship between the ability of the application of agribusiness business with the characteristics of breeders, entrepreneurial spirit with the success of agribusiness. In addition, there is also evidence that there is a relationship between the capability of applying agribusiness with the success of agribusiness.

Saputro (2009) examines the characteristics of dairy goat breeder entrepreneurs in Bogor district, West Java. The research was conducted in March-May 2009 on dairy goat farm in Bogor Regency. The respondents were seven respondents who were dairy goat breeders in Bogor Regency. Determination of respondents by judgment sampling and snowball sampling. The characteristics of the entrepreneurs studied are confidence, task-oriented and results, courage to risk, leadership, originality, and futureoriented. Methods of data collection using observation techniques, interviews, and filling questionnaires. Method of data processing using descriptive analysis and descriptive statistics. These results indicate that the characteristics of prominent entrepreneurs in high school graduates is a future orientation whereas in high education graduates is the courage to risk. The most prominent entrepreneurial characteristic of the beginner breeder is task-oriented and result, while the 
middle farmer is the leader. The most prominent entrepreneurial characteristic in the early adult breeder is the courage to risk. While the most prominent entrepreneurial characteristics in the middle-aged breeders are self-confidence, and the final adult breeder is leadership.

Sudirman (2005) studied on integrated business training for PERHUTANI farmers. From this research, it can be concluded that integrated business skill training model for horticultural farmer community of Perhutani farmers in Bandung Regency has been able to give solution to society to rediscover their livelihood. Farmers who originally only grow vegetables, are now able to grow and switch to other commodities such as; farming bananas, raising cattle, raising rabbits, and buying and selling.

Anwar (2004), through research of Development of Culture-Based Culture-Based Skill Model for Women Fishermen, provides evidence that in learning and training activities begins with the process of awareness. If previously people always closed, it turns out after joining the community training to be open and willing to accept new ideas developed. In the learning model, fishermen women are given some kind of skill training, the result is that people are able to apply their skills to be a livelihood. The community becomes skilled at exploiting the potential of the environment to be developed and made in addition to family income.

\section{RESEARCH METHODS}

\subsection{Implementation Method}

This research was conducted by using Kaji Actions approach. The research studies used in this study are descriptive analytic. Through descriptive research, the outline has two objectives; First, to know the potential and development of existing resources, or the frequency of occurrence of certain aspects of social phenomena. Second, to describe in detail about certain social phenomena. The hypothesis in this study without using such a strict formula, although sometimes using hypothesis, but not to be tested with statistics in depth (Prasetijo, 2003). While analytically, the analysis uses a method that aims to test the results statistically, and the results serve to strengthen the answers descriptively according to the problems posed in the study. In general, this study study aims to see the results of the training that has been implemented, namely to determine the difference between participants before and after training skill training.

\subsection{Research Procedures}

Research model of integrated business skill training for farmers as community empowerment effort implemented through two forms of activity in two years. The first year the researcher conducted a qualitative exploration, and the second year experimental design. Exploration study activities are conducted by researching and gathering information about development needs (Teguh, 2004). The exploratory study in the first year of the study consists of four stages and is summarized in 2 main stages of preliminary study and Conceptual Model Formulation (Moleong, 2007). This paper emphasizes the results of preliminary exploratory studies and exploratory early action. As a form of research using descriptive analytic design, the authors do the exploration by collecting descriptive data as much as possible and pour it in the form of reports and descriptions. While analytical activities are carried out throughout the research process. Along with exploration activities, libraries are also studied in accordance with the topics to be studied, such as: (1) reviewing and defining the main theories used as the basis of the study such as integrated business skills training theory and entrepreneurship theory, (2) studying and defining the concepts of theories principal as the basis for modeling such as; training theories, learning theories and empowerment theories.

In exploration activities in the preliminary study is divided into three stages:

1) Preparation; at this stage the researcher prepares everything necessary to conduct a preliminary study such as the maintenance of a spaciousness permit, and the various instruments required in the research activity. In the preparation stage, development of identification instruments such as; (a) interview guides and checklists for farmers, a checklist is given for obtaining data and information relating to selfidentity, farmer characteristics such as; interests, talents, skills, problems and learning needs of program target candidates, (b) interview guidelines for related agencies and prospective tutors.

2) In Depth Survey; In this activity, the researcher observes and records the condition of the research object, identifies the problem, conducts the survey needs survey and confirmation of survey results with the village head in Kawedegan Hamlet, Balonggebang 
Village, Gondang Subdistrict, Nganjuk Regency. The purpose of the in-depth survey is to collect and examine the appropriate data, and as objectively as possible about the condition of the research object and carried out systematically. From the collected data then analyzed and interpreted to memeperbaiki existing conditions. After the survey results of the general description of the condition of the community of farmers in the Hamlet Kawedegan, Balonggebang Village, Gondang District, Nganjuk obtained, the researchers then conducted interviews with assistance interview guide against some officials and related agencies in connection with research activities undertaken. The purpose of the interview is to know the action plan or program that will be developed in Kawedegan Hamlet, Balonggebang Village, Gondang Subdistrict, Nganjuk Regency, especially to the farmer community of Perhutani land. From the result of the survey, the result of the survey could be to answer the formulation of the problem (special), namely: (a) how the objective condition experienced by the farmer community of Perhutani land in Kawedegan, Balonggebang Village, Gondang Subdistrict, Nganjuk, (b) coaching or training, and (c) whether integrated business skills training is required by the community in Kawedegan /Hamlet, Balonggebang Village, Gondang District, Nganjuk District.
3) Needs analysis; to find appropriate training needs for horticulture farming communities in Suntenjaya village that are practical and applicable. Needs analysis activity is done before determining the type of training, that is by discussing result of interview activity with prospective trainee, and reinforced from input result of interview with village head, local community figure, and party of Perhutani East Java. In the analysis phase of the needs studied include; (a) an analysis of the capabilities that farmers currently possess, (b) analysis of expected problems and needs in training, and (c) analysis of potential resources that can be developed. From the results of the analysis or assessment, the researcher will be able to determine the type of training required in developing the business capability.

\section{RESEARCH FINDINGS AND DISCUSSION}

\subsection{Participant Profile}

Nineteen people have participated in the Focus Group Discussion, Business Sector: livestock (cows, goats, ducks, mentog), food and beverages, paddy Farmers, and retailers. Farmers do not have good access to markets.

\begin{tabular}{|l|l|}
\multicolumn{2}{|c|}{ Table 4.1 } \\
\hline Marketing Coverage & \multicolumn{1}{|c|}{$\begin{array}{l}\text { a. Do a preliminary research } \\
\text { b. Create a marketing plan } \\
\text { c. Product development to attract untapped customers } \\
\text { d. Make a competitive price } \\
\text { e. Request customer opinion or the product } \\
\text { f. Invite people to come to the place of business } \\
\text { g. Create a unique product } \\
\text { h. Create messages and marketing materials } \\
\text { i. Etc }\end{array}$} \\
\hline
\end{tabular}

\subsection{General Outcomes Sharing Experience of SMEs Entrepreneur}

It is not uncommon for SMEs to suffer business losses. For agricultural products the price given by the middleman is very low, being in debt in the Credit Unions so that the expected profit is not obtained. For other businesses difficult to market the product because it does not know the market accesc. Fear of Resistance of the comfort zone between farmers also impedes the opportunity for the growth of community empowerment efforts in Kawedegan.

\subsection{Problems and Obstacles of Entrepreneurship}

The role of local government for SMEs to be more developed in various fields seems to have not shown encouraging results, programs that made less touched the target for the perpetrators of their business, in addition to the policies made also many that are not followed in action tangible, so impressed can only make but difficult to implement. In addition, the 
phenomenon of underdevelopment of entrepreneurship in Kawedegan in general is also inseparable from the problems that come from internal factors of the company and external business environment, so the consequences of improvements become more complex and demands all of us to manage these complexities together.

The problem is then, how we can encourage business actors and entrepreneurs prospective SMEs not lose direction, have a high motivation and tenacity. Given the guidance and development of SMEs is one activity in the economic field that has a strategic meaning in order to empower the community of hamlet kawedegan without eliminating wisdom and local potential. This can contribute significantly to the creation of business fields, expansion of employment opportunities and employment and income generation that can ultimately provide community livelihoods.

To be able to realize the goal is not easy, it needs guidance and development of SMEs continuously and continuously with dynamic policy and according to condition and aspiration of business actor. This is because it is not a secret that the business actors in the region, especially SMEs groups do not have a voice, and rarely can champion their interests professionally.

\subsection{Entrepreneurial SWOT Analysis}

One of the things that make a small business business go forward and reap good results is in careful business planning. One of the business success tips is on business planning based on an analysis of several factors that will affect the continuity of the business undertakings. This business analysis plays an important role for small businesses. Usually the analysis of these factors is ignored by small business actors. Understandably small business business is usually run according to "instinct", although many successful business in that way but it would be nice if based on the analysis and planning is mature, evaluation of business development, improvement, innovation, business competition analysis and others.

In business continuity, there are two things that can affect the success of the business. First Factor Internal and Both External Factors. SWOT analysis is used to identify internal and external factors that are important in achieving the objectives. Internal factors; internal strengths and weaknesses of business organizations. External factors; threats and opportunities that exist in the external environment of business organizations.

By knowing the weaknesses of the company, immediately anticipate that the weakness does not cause a failure of a business. After analyzing the weaknesses owned by the business, as much as possible immediately take steps to overcome these weaknesses. A simple example, if the weakness is on the factor of production is slow because the old production equipment must be overcome by replacing the newer production tools. Or modify tools more efficiently and effectively.

The strength possessed is the potential that needs to be highlighted and made the capital to achieve success. Suppose we have a product that has a quality above the average of similar products, this can be used as an ingredient in a promotional approach. Opportunities as well as Strength is a positive thing from the outside that needs to be captured and used as the foundation for running a business wheel. One example, suppose there is a market opportunity demand for a product is very large. This is an opportunity that needs to be immediately captured to be a business field.

The number of opportunities a business will certainly be followed by the many competitors who move in the same business. This poses a threat to our business. The threat of such competitors needs to be anticipated by several steps. For example by improving product quality, product yariations or better marketing methods. As much as possible minimize weaknesses and threats but strengthen strength and potential.

SWOT analysis approach helps SMEs to know the potential of self, strength, weakness as well as opportunities and threats that exist around the business. That way we can do a strategic plan for the business. Performing SWOT analysis is one of the Business Success Tips that can be taken. 
Table 4.2. SWOT SMEs Kawedegan Village Nganjuk

\begin{tabular}{|c|c|}
\hline $\begin{array}{l}\text { Strenght } \\
\text { - Community economic empowerment } \\
\text {. Market for products } \\
\text {. Motivated and honest workforce }\end{array}$ & $\begin{array}{l}\text { Weakness } \\
\text { Limited Facilities and Business Infrastructure } \\
\text { Lack of capital resulted in SMEs can not } \\
\text { survive } \\
\text { - Limited availability of fertilizer raw materials } \\
\text { for farmers } \\
\text { *imited knowledge gained additional capital. }\end{array}$ \\
\hline $\begin{array}{l}\text { Opportunities } \\
\text { * Public acceptance of SMEs products } \\
\text { Credit assistance for SMEs } \\
\text { Possible production efficiency. }\end{array}$ & $\begin{array}{l}\text { Threats } \\
\text { Strict business competition } \\
\text { Limited Market Access }\end{array}$ \\
\hline
\end{tabular}

\subsection{Strategy of SMEs Development}

Various ways can be taken for the development of SMEs and Entrepreneurship in the Kawedegan Village include:

\section{Involvement in Value Chains}

Value chain is defined as the activities necessary to bring the product or service from start of concept, production process, to delivery of goods / services to the consumer. SMEs can act as partners of large companies in this chain. This relationship can be very beneficial to both parties because of the characteristics of SMEs are more flexible and transaction costs are cheaper because it is closer to consumers and faster decisions while large companies utilize the size of a large (economic of scale). For example, farmers should not be dependent on middlemen to sell their agricultural products.

\section{Develop a Niche Market}

Developing a niche market is one of the important strategies for SMEs. In this strategy SMEs chooses to be a player in a very specific product. By implementing this strategy, SMEs not only can compete with big companies but also can reach the market. In an industry with product differentiation, SMEs growth is highly dependent on the ability to create niche markets and avoid head-on competition (Saiman 2009)

\section{Networking}

Networking is a link, both formal and informal. In the global era, inter-company networks can help SMEs to compete parallel to large companies. Network can also speed up the learning process. They can facilitate the configuration of relationships with suppliers that enable companies to innovate and improve efficiency with collaborative activities. The facts prove that community relationships play an important role in business networks. The common cultural background, beliefs and behaviors make it easy for members of ethnic groups to predict and understand the behavior and needs of other members.

The social-based network provides a way for companies to find business partners, including trade associations and industries that can provide benefits that SMEs cannot get individually. MFIs collaboration in a network can facilitate opportunities, for example to participate in exhibitions, make contact with producers or consumers, upgrade technology, new product development, product standard improvement and to fend off global market threats (Robinson, 2001).

One of the outputs of this activity is the establishment of Micro Finance Institutions (MFIs) to strengthen access to finance for land tenure farmers PERHUTANI, Kawedegan, Balonggebang Village, Gondang District, Nganjuk-East Java. The farmers of this PERHUTANI farmers are seeking funding support to start developing their business independently. On 1 September 2013 a credit MFIs in Kawedegan, Balonggebang Village, Gondang district, 
Nganjuk was formed. Credit unions are one of the effective methods of economic empowerment of people to build trust and mobilize a grassroots base to support rural development programs.

Why should MFIs be the choice of village community financial management, not commercial banks? The problem is not solely difficult for people to get access to credit in the bank due to bureaucracy and complicated requirements, but because in the activities of MFIs there is a spirit of unifying ties. The principles that must be built in the MFIs are openness, trust and togetherness. With openness to all things about finance in the MFIs is expected to emerge a trust that can ultimately build and strengthen togetherness. MFIs activities are implemented in an effort to strengthen social and financial capital in the community in the hope of supporting the implementation of entrepreneurship activities of the farmer's community.

The wishes or desires of the villagers in KawedeganBalonggebang Village, Gondang District, Nganjuk District, the function and role of microfinance institutions are the providers of venture capital. Aside from being a venture capital provider, approximately $59.65 \%$ of respondents mentioned that MFIs can function as a provider of savings and loan services, and only about $29.82 \%$ mention MFI as an institution that collects funds from the community. In its implementation the MFI is considered more efficient than other financial institutions because of its proximity to the communities it serves. This proximity will reduce transaction costs. MFIs in operations also provide non-financial assistance facilities. For example, we try to help the farmers to create a business plan, recording and financial bookkeeping group.

The role of $\mathrm{CU}$ (Credit Union) by most people working in the industrial sector is more important as a provider of savings and loan services, whereas as a community fund-raising institution only a small proportion indicates. On the one hand MFIs have advantages that are relatively not owned by commercial banks, namely: locations that can be reached by small and micro entrepreneurs, have flexibility in conducting transactions with customers that are not considered bankable, and better understand the culture of the local community because of its existence psychologically or familially between MFI managers and their members.

\section{CONCLUSION}

The findings of this study are still the result of a preliminary exploratory study that needs to be followed up with actions other than the establishment of a microfinance institution. The hamlet community of Kawedegan needs mentoring and various necessary training. The integrated training model is currently being developed by the team to provide appropriate training to enhance the community managerial skills that participate in the program. In addition, efforts to improve welfare are also highly dependent on the willingness of the community to change, work harder and learn from experience, training and new practices that have not been applied.

One of the first outputs of this activity is the establishment of Micro Finance Institutions (MFIs) to strengthen access to finance for land tenure farmers PERHUTANI Kawedegan Hamlet, Balonggebang Village, Gondang District, Nganjuk District. The farmers of this PERHUTANI farmers are seeking funding support to start developing their business independently. It is expected to be the initial driving force to make Kawedegan's hamlet economy begin to move toward progress.

\section{BIBLIOGRAPHY}

1. Anwar. (2004). Pengembangan Model Pengelolaan Pembelajaran Keterampilan Berbasis Sosial Budaya bagi Perempuan Nelayan. (Studi Perubahan Sosial Melalui Introduksi Teknologi pada Keluarga Nelayan Suku Bajo di Kabupaten Kendari). Disertasi. UPI Bandung.

2. Moleong, L. J., 2007, Metodologi Penelitian Kualitatif, Penerbit PT Remaja Rosdakarya, Offset, Bandung.

3. Prasetijo, A. 2003. Akses Peran Serta Komuniti Lokal dan Pengeloaan Sumber Daya Alam dalam Akses perta Masyarakat. Penerbit ICD: Jakarta.

4. Robinson,M. S., 2001, The Microfinance Revolution, Sustainable Finance for the Poor, The World Bank

5. Saiman, L., 2009, Kewirausahaan: Teori, Praktik dan Kasus-kasus, Salemba Empat, Jakarta

6. Saputro, Dani Sudibyo. 2009. Analisis Karakteristik Wirausaha Peternak Kambing Perah di Kabupaten Bogor Jawa Barat. Skripsi. Fakultas Ekonomi Manajemen Institut Pertanian Bogor. 
7. Sudirman. 2005. Model Pelatihan Keterampilan Usaha Terpadu Bagi Petani Sebagai Upaya Alih Komoditas". (Studi Terhadap Petani Penggarap Lahan Perhutani di Desa Suntenjaya Kecamatan Lembang Kabupaten Bandung). Disertasi. UPI Bandung.

8. Sukarta. 2010. Pengaruh lingkungan, sifat kewirausahaan, dan motivasi wirausaha terhadap pembelajaran wirausaha serta kinerja usaha. Tesis. Unud: Denpasar

9. Teguh, A. S. 2004. Kemitraan dan Model-model Pemberdayaan. Penerbit Gaya Media, Yogyakarta.

10. Udayani, R. 2010. Hubungan Antara Jiwa Kewirausahaan dengan Keberhasilan Usaha Agribisnis (Kasus pada Usaha Peternakan Ayam Ras Pedaging di Bali). Tesis. Unud: Denpasar. 